\title{
KARAKTERISTIK COOKIES DARI CAMPURAN TEPUNG UBIKAYU TERMODIFIKASI (MOCAF), TEMPE, TELUR, KACANG HIJAU DAN IKAN LELE
}

\section{CHARACTERISTIC OF COOKIES FROM MODIFIED CASSAVA FLOUR (MOCAF), EGG, TEMPE, MUNG BEAN AND CATFISH FLOURS COMPOSITE}

\author{
Muhamad Kurniadi' ${ }^{1}$, Mukhamad Angwar ${ }^{1}$, Miftahkussolikhah'1, \\ Dian Rachmawanti Affandi², Nila Khusnia ${ }^{2}$ \\ ${ }^{1}$ Balai Penelitian Teknologi Bahan Alam Lembaga IImu Pengetahuan Indonesia, Gunung Kidul, \\ Yogyakarta \\ 2Jurusan Teknologi dan IImu Pangan Universitas Negeri Sebelas Maret, Surakarta \\ e-mail:hm kur@yahoo.com
}

Diterima : 03 Agustus 2018; Direvisi : 03 Agustus - 26 Desember 2018; Disetujui : 25 Juli 2019

\begin{abstract}
Abstrak
Saat ini, stunting menjadi salah satu permasalahan nasional yang harus segera dicari pemecahannya. Pemberian makanan tinggi kalori, protein dan zat gizi mikro dapat menurunkan resiko balita stunting. Permasalahannya, makanan selingan dengan spesifikasi tersebut biasanya mahal sehingga perlu dicari alternatif makanan yang murah dan mudah mendapatkanya. Tujuan penelitian ini yaitu menentukan karakteristik kimia, fisika dan sensoris cookies dari campuran tepung mocaf, tempe, kacang hijau dan ikan lele. Formula bahan tepung campuran yaitu F1 (mocaf 68\%, tepung tempe telur 5\%, tepung kacang hijau $12 \%$, tepung ikan lele $15 \%$ ), F2 (mocaf $63 \%$, tepung tempe telur $5 \%$, tepung kacang hijau $12 \%$, tepung ikan lele $20 \%$ ), dan F3 (mocaf 58\%, tepung tempe telur 5\%, tepung kacang hijau 12\%, tepung ikan lele $25 \%$ ). Hasil penelitian menunjukkan bahwa cookies yang paling disukai panelis adalah formula F1 dan F2. Hasil analisis fisik menunjukkan bahwa ketiga formula cookies memiliki kisaran warna merah kekuningan, serta memiliki tingkat kekerasan yang tidak berbeda nyata. Formula terpilih sebagai cookies potensial menurunkan resiko stunting adalah cookies F2 yang dapat dikonsumsi 5-10 keping per hari, mempunyai komposisi gizi yaitu protein $12,06 \%$, lemak $20,99 \%$,karbohidrat $59,17 \%$ dan energy $511,56 \mathrm{kkal} / 100 \mathrm{~g}$.
\end{abstract}

Kata Kunci : cookies, mocaf, stunting, tepung ikan lele

\section{Abstract}

Currently, stunting becomes one of the national issues that must be solved immediately. Intake of high calorie, high protein and high micronutrients food can reduce the risk of toddlers stunting. Its goals were to determine the chemical, physics and sensory characteristics of cookies were made from a mixture of mocaf, tempe, eggs, mung bean and catfish. The compotition of cookies were F1, F2 and F3. The results show that the most preferred cookies was formulas F1 and F2. The results of physical analysis showed that the three formulas of cookies have a yellowish red color, and have a level hardness that is not significantly different. The formula chosen as potential cookies lowering the risk of stunting is the F2 (mocaf 63\%, egg tempe flour 5\%, mung bean flour $12 \%$, fish flour catfish $20 \%$ ) cookies that can be consumed 5-10 pieces per day, has a nutritional composition that is $12.06 \%$ protein, $20.99 \%$ fat, $59.17 \%$ carbohydrate and $511.56 \mathrm{kcal} / 100 \mathrm{~g}$ energy.

Keywords: cookies, mocaf, stunting, catfish flour

\section{PENDAHULUAN}

Sekarang ini, stunting merupakan salah satu permasalahan yang perlu segera ditangani di Indonesia. Menurut Riskesdas pada tahun 2013, sekitar $37 \%$ (sekitar 9 juta) anak di Indonesia mengalami stunting di berbagai kelompok pendapatan, menempati urutan 5 besar dunia. (Badan Penelitian dan Pengembangan Kemenkes RI, 2013). Balita pendek (stunted) dan sangat pendek (severely stunted) adalah balita dengan panjang badan (PB/U) atau tinggi badan (TB/U) menurut umurnya dibandingkan dengan standar baku WHO-MGRS (Multicentre Growth Reference Study) 2006. Sedangkan definisi stunting menurut Kementerian Kesehatan (Kemenkes) adalah anak balita dengan nilai z-scorenya kurang dari 2SD/standar deviasi (stunted) dan kurang dari - 3SD (severely stunted)1. Balita/Baduta (Bayi dibawah usia Dua Tahun) yang mengalami stunting akan memiliki tingkat kecerdasan tidak maksimal, menjadikan anak menjadi lebih rentan terhadap penyakit dan di 
masa depan dapat beresiko pada menurunnya tingkat produktivitas. Pada akhirnya secara luas stunting akan dapat menghambat pertumbuhan ekonomi, meningkatkan kemiskinan dan memperlebar ketimpangan (Tim Nasional Percepatan Penanggulangan Kemiskinan, 2017).

Salah satu penyebab stunting pada anak adalah kurangnya akses rumah tangga (calon orangtua, ibu hamil maupun balita) pada makanan bergizi. Intervensi gizi spesifik dengan sasaran ibu hamil, ibu menyusui dan anak usia 023 bulan merupakan salah satu upaya dalam penanganan stunting. Berlatar dari permasalahan tersebut, perlu dicari alternatif makanan dengan kalori tinggi serta memenuhi kebutuhan protein dan zat gizi mikro. Salah satu jenis makanan selingan yang dapat dijadikan sebagai alternatif pemenuhan energi dan protein adalah cookies. Menurut Manley (2001), cookies termasuk salah satu jenis biskuit berupa produk hasil pengovenan berukuran kecil berbahan baku tepung terigu dengan penambahan lemak, gula, dan bahan bahan lain.

Pada penelitian ini dibuat cookies menggunakan tepung mocaf (modified cassava flour) dengan campuran tepung tempe telur, kacang hijau dan ikan lele. Mocaf merupakan salah satu sumber karbohidrat dengan kandungan karbohidrat cukup tinggi, yaitu sebesar 94,68\% (Nurhikmat dan Kurniadi, 2013). Penggunaan mocaf dapat meminimalisir penggunaan terigu serta lebih mudah dicerna terutama bagi balita karena bebas gluten. Tepung tempe telur merupakan tepung yang terbuat dari campuran bahan tempe dan telur yang telah mengalami proses pengeringan dan penepungan. Tepung tempe telur mengandung protein sebesar 42,24\% (Angwar et al., 2007), sehingga penggunaannya disini dapat meningkatkan kadar protein dan zat gizi lain pada cookies. Tepung kacang hijau memiliki kandungan pati sebesar $61,77 \%$, dan kadar protein sebesar $23,53 \%$ (Ladamay et al., 2014). Ikan, termasuk lele selama ini sudah digunakan sebagai sumber protein termasuk dalam berbagai industri makanan, pakan, farmasi, kosmetik dan pupuk (Halim et al., 2016). Pemilihan ikan lele dalam penelitian ini karena mudah didapatkan dan harganya relatif murah. Ikan lele mempunyai kandungan protein relatif tinggi yaitu $16 \%$ menurut USDA (2018) sementara pada tepung ikan lele sebesar $63,83 \%$ (Mervina, 2009).

Tujuan penelitian ini yaitu mengetahui karakteristik kimia fisika dan sensoris cookies dari bahan baku tepung mocaf, tepung tempe telur, tepung kacang hijau, dan tepung ikan lele. Selanjutnya diharapkan cookies yang dihasilkan dapat dimanfaatkan sebagai makanan selingan tinggi kalori, protein dan zat gizi mikro bagi wanita usia subur dan balita sehingga dapat menurunkan resiko stunting.

\section{BAHAN DAN METODE}

\section{A. Bahan dan Alat}

Bahan yang digunakan dalam penelitian ini antara lain mocaf, kacang hijau, ikan lele, tempe, telur dan bahan lain untuk pembuatan cookies. Bahan kimia pro analisis seperti : $\mathrm{CuSO}_{4}$, $\mathrm{H}_{2} \mathrm{SO}_{4}, \mathrm{HCl}, \mathrm{Na}_{2} \mathrm{CO}_{3}$, petroleum eter dan $\mathrm{NaOH}$ untuk analisis kimia diperoleh dari distributor bahan kimia di Yogyakarta.

Peralatan yang digunakan antara lain pengukus, kempa hidrolik, oven, alat kjeldahl, soxlet, muffle furnace, dan alatalat gelas laboratorium.

\section{B. Metode penelitian Pembuatan Tepung Campuran}

Formulasi tepung campuran dilakukan dengan perhitungan nilai gizi makro masing-masing bahan pada setiap formula. Tepung-tepung yang telah dibuat, ditimbang sesuai dengan formula masing-masing. Formula perbandingan tepung campuran dapat dilihat pada Tabel 1 .

Tabel 1. Formula Tepung Campuran

\begin{tabular}{ccccc}
\hline Formula & $M$ & Ttt & Tkh & Til \\
\hline F1 & 68 & 5 & 12 & 15 \\
F2 & 63 & 5 & 12 & 20 \\
F3 & 58 & 5 & 12 & 25 \\
\hline
\end{tabular}

Keterangan : 


$\begin{array}{ll}\text { M } & \text { : Mocaf } \\ \text { Ttt } & : \text { Tepung temped an telur } \\ \text { Tkh } & : \text { Tepung kacang hijau } \\ \text { Til } & : \text { Tepung ikan lele }\end{array}$

Kemudian dicampur menggunakan blender sampai homogen. Setelah itu dikeringkan pada suhu $45-55^{\circ} \mathrm{C}$ selama 8 jam, bertujuan untuk mengurangi kadar air pada tepung campuran.

\section{Pembuatan Cookies}

Bahan dasar cookies terdiri dari tepung komposit $100 \mathrm{~g}$, gula halus $60 \mathrm{~g}$, mentega $50 \mathrm{~g}$, kuning telur $32 \mathrm{~g}$, susu skim $58 \mathrm{~g}$, baking powder, 25 dan pasta moca $9 \mathrm{~g}$. Proses pembuatan cookies dimulai dengan pembuatan adonan. Kocok mentega dan gula halus, ditambahkan kuning telur dan dicampur hingga homogen. Tambahkan pasta moca dan diaduk hingga rata. Kemudian ditambahkan bahan kering yaitu tepung komposit, susu skim, dan baking powder yang sebelumnya telah dicampur dan diayak terlebih dahulu. Diaduk menggunakan spatula hingga rata. Selanjutnya adonan digilas dengan rolling pin lalu dicetak. Terakhir dilakukan pemanggangan dengan oven pada suhu $180{ }^{\circ} \mathrm{C}$ selama 18 menit.

Diagram alir pembuatan cookies dapat dilihat pada Gambar 1.

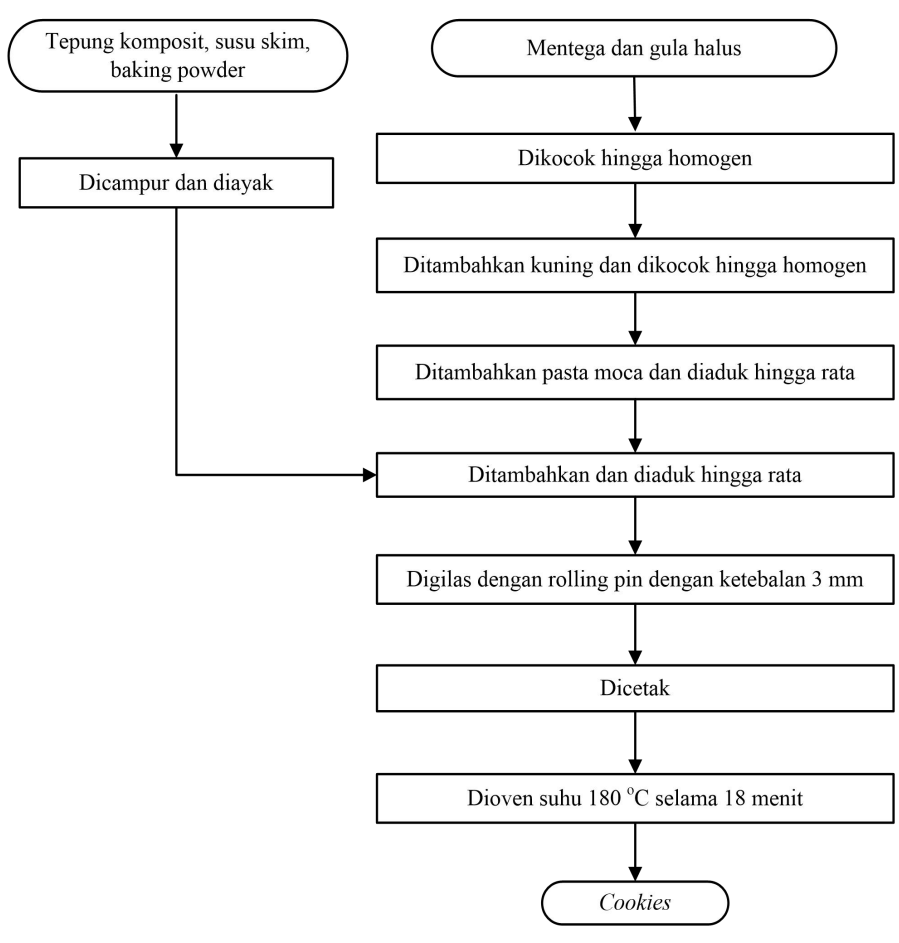

Gambar 1. Diagram alir pembuatan
cookies

\section{Analisis Fisik Cookies Warna}

Pengukuran warna cookies dengan menggunakan chromameter. Chromameter menggunakan alat Color Reader CR-400/410 dengan sistem warna berupa Hunter's Lab Colorimetric System.

Pada sistem warna ini terdapat tiga parameter yaitu L (Lightness), $a^{*}$ (Redness), dan b* (Yellowness). Notasi L menyatakan parameter kecerahan (lightness) dengan kisaran nilai dari 0100 menunjukkan dari gelap ke terang. Nilai $L$ yang semakin besar menunjukkan warna yang semakin terang dan sebaliknya semakin kecil nilai lightness menunjukkan warna semakin gelap. Notasi a (Redness) memiliki kisaran nilai dari $(-80)$ sampai $(+100)$ menunjukkan dari hijau ke merah.Notasi b (yellowness) dengan kisaran nilai dari (-70) sampai $(+70)$ menunjukkan dari biru ke kuning, dimana b positif menunjukkan warna kuning dan nilai $b$ negatif menunjukan warna biru.

\section{Tekstur}

Pengukuran tekstur dilakukan secara obyektif menggunakan alat Lloyd universal testing machine. Kekerasan cookies dapat diukur sebagai respon bahan terhadap gaya yang diberikan. Pada pengukuran ini akan muncul kurva hubungan antara gaya dan waktu. Nilai Fmaks atau gaya maksimal menunjukkan tenaga maksimum pada alat yang diperlukan untuk menekancookiessampai terjadi kerusakan pada cookiesdengan satuan Newton (N). Semakin besar nilai $F$ maks maka semakin tinggi tingkat kekerasan cookies

\section{Pengujian Kesukaan Cookies}

Pengujian kesukaan pada cookies untuk memprediksi tingkat kesukaan konsumen terhadap cookies meliputi aspek warna, tekstur, aroma, rasa, dan keseluruhan (overall) dengan metode skoring skala nilai $1=$ sangat tidak suka 
sampai dengan $5=$ sangat suka dengan menggunakan 25 orang panelis semi terlatih. Pada pengujian ini panelis diminta untuk menilai sampel berdasarkan kesenangannya menurut skala nilai yang sudah disediakan (Setyaningsih et al., 2010).

\section{Analisis Kimia}

Analisis kimia dilakukan pada ketiga formula cookies, yaitu : kadar air (Thermogravimetri), kadar abu, kadar protein (Mikro Kjeldhal), kadar lemak (Soxhlet), karbohidrat (by different) dan total kalori, (Sudarmaji et al., 2010).

\section{Rancangan percobaan dan analisis data}

Penelitian ini menggunakan Rancangan Acak Lengkap (RAL) dengan satu faktor, yaitu formula tepung campuran mocaf, tepung tempe telur, tepung kacang hijau, dan tepung ikan lele. Data yang diperoleh dianalisis secara statistik dengan ANOVA dan dilanjutkan dengan uji Duncan's Multiple Range Test (DMRT) dengan tingkat signifikan (a) $5 \%$.

\section{HASIL DAN PEMBAHASAN}

\section{A. Sifat Fisik Cookies Warna}

Pengujian warna dilakukan untuk mengetahui warna suatu produk secara obyektif. Pengujian sifat fisik warna cookies dilakukan dengan alat chromameter menggunakan metode hunter (Sanchez et al., 2014) dengan hasil pengukuran disajikan pada Tabel 2 .

Tabel 2. Nilai L, a, b dan ${ }^{0}$ Hue pada cookies campuran tepung mocaf, tempe telur, kacang hijau, dan ikan lele

\begin{tabular}{lcccc}
\hline Cookies & $\mathrm{L}$ & $\mathrm{a}$ & $\mathrm{B}$ & ${ }^{0}$ Hue \\
\hline F1 & $44,94 \pm 0,13^{\mathrm{b}}$ & $14,93 \pm 0,18^{\mathrm{b}}$ & $27,67 \pm 0,11^{\mathrm{a}}$ & $61,64 \pm 0,20^{\mathrm{a}}$ \\
F2 & $45,50 \pm 0,22^{\mathrm{b}}$ & $14,44 \pm 0,12^{\mathrm{a}}$ & $27,02 \pm 0,14^{\mathrm{a}}$ & $61,88 \pm 0,09^{\mathrm{a}}$ \\
F3 & $43,48 \pm 0,48^{\mathrm{a}}$ & $14,78 \pm 0,25^{\mathrm{ab}}$ & $26,84 \pm 1,06^{\mathrm{a}}$ & $61,14 \pm 0,71^{\mathrm{a}}$ \\
\hline
\end{tabular}

Keterangan

Notasi yang berbeda pada kolom yang sama

menunjukkan beda nyata pada $\alpha 5 \%$

$\mathrm{F} 1=m o c$

Dari Tabel 2, diketahui bahwa nilai $L$ (kecerahan) cookies F3 paling rendah yaitu 43,48. Nilai L cookies F1 dan F2 berbeda nyata dengan nilai $L$ cookies $F 3$, sedangkan cookies F1 dan F2 tidak berbeda nyata pada tingkat signifikansi $5 \%$. Cookies F1 dan F2 memiliki nilai L sebesar 44,94 dan 45,50. Nilai (a) pada cookies $\mathrm{F} 1$ berbeda nyata dengan cookies F2, sedangkan cookies F3 tidak berbeda nyata dengan cookies $\mathrm{F} 1$ dan F2. Untuk nilai (b) tidak ada perbedaan nyata pada ketiga formula cookies.

Hasil pengukuran nilai $a^{*}$ dan $b^{*}$ pada sistem warna Hunter dapat dikonversikan kedalam satuan kromatik ${ }^{0}$ Hue (Pradana et al., 2013).

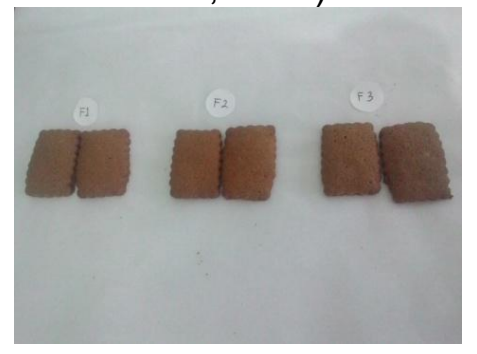

Gambar 2. Cookies berbagai formula

Pemanasan karbohidrat pada suhu tinggi menyebabkan karamelisasi yang akan mempengaruhi warna dan aroma produk (Mendenhall dan Hartel, 2016). Reaksi antara gugus amino pada asam amino dari tepung kacang hijau, tepung tempe telur, tepung ikan lele, telur dan susu skim dengan gugus hidroksil glikosidik pada gula mengakibatkan terjadi pembentukan polimer nitrogen yang berwarna coklat yang disebut sebagai reaksi maillard (Kocadagli \& Gokmen, 2016).

\section{Tekstur}

Hasil pengukuran tekstur cookies disajikan pada Tabel 3.

Tabel 3. Nilai F maks. cookies, tepung mocaf, kacang hijau, tempe telur dan tepung ikan lele

\begin{tabular}{cc}
\hline Cookies & F Maks. (N) \\
\hline F1 & $24,25 \pm 0,87^{\mathrm{a}}$ \\
F2 & $21,63 \pm 0,90^{\mathrm{a}}$ \\
F3 & $21,91 \pm 1,08^{\mathrm{a}}$ \\
\hline
\end{tabular}

Keterangan:

Notasi yang berbeda pada kolom yang sama menunjukkan beda nyata pada $\alpha 5 \%$ 
Dari nilai F ketiga formua cookies tersebut tidak menunjukkan perbedaan pada tingkat signifikansi sebesar $5 \%$. Dari hasil tersebut menunjukkan bahwa semakin banyak penambahan tepung mocaf maka tingkat kekerasan cookies akan semakin besar. Singkong sebagai bahan baku mocaf mengandung kadar amilosa di kisaran 2,5-12\% (Hernandez et al., 2012). Sehingga, semakin banyak rasio mocaf pada cookies menghasilkan cookies yang semakin keras.

\section{B. Karakteristik Sensori Cookies}

Nilai kesukaan terhadap formula cookies campuran mocaf, tepung tempe telur, tepung kacang hijau dan tepung ikan lele disajikan pada Tabel 4.

Tabel 4. Nilai Kesukaan terhadap Cookies

\begin{tabular}{llllll}
\hline Formula & \multicolumn{5}{c}{ Parameter } \\
\cline { 2 - 6 } Cookies & Warna & Aroma & Rasa & Tekstur & Overall $^{\text {Conyyyy}}$ \\
\hline F1 & $3,64^{\mathrm{a}}$ & $3,64^{\mathrm{a}}$ & $3,80^{\mathrm{a}}$ & $3,84^{\mathrm{a}}$ & $3,92^{\mathrm{b}}$ \\
F2 & $3,72^{\mathrm{a}}$ & $3,64^{\mathrm{a}}$ & $3,80^{\mathrm{a}}$ & $4,00^{\mathrm{a}}$ & $3,92^{\mathrm{b}}$ \\
F3 & $3,32^{\mathrm{a}}$ & $3,28^{\mathrm{a}}$ & $3,36^{\mathrm{a}}$ & $3,56^{\mathrm{a}}$ & $3,40^{\mathrm{a}}$ \\
\hline
\end{tabular}

Keterangan:

Notasi yang berbeda pada kolom yang sama menunjukkan beda nyata pada a $5 \%$

Dari Tabel 4 terlihat bahwa nilai kesukaan yang tidak berbeda secara nyata pada tingkat kesukaan warna cookies. Demikian juga tingkat kesukaan aroma cookies tidak berbeda nyata pada tiga formula. Nilai kesukaan aroma pada cookies F3 paling rendah. Hal ini dikarenakan penggunaan tepung ikan lele yang semakin banyak dan menghasilkan aroma amis yang relatif lebih tajam (Imandira, 2012). Pemberian bahan tambahan lain seperti pasta moka dan mentega akan berpengaruh pula pada aroma cookies. Tingkat kesukaan terhadap atribut rasa cookies tidak berbeda nyata pada F1, F2 dan F3. Namun, cookies dengan formula F3 mempunyai tingkat kesukaan terhadap rasa paling kecil dapat disebabkan penggunaan tepung ikan lele dengan rasio paling tinggi sehingga menghasilkan aroma dan rasa yang lebih amis dibanding formula lain.

Tingkat kesukaan tekstur ketiga formula cookies tidak berbeda nyata.
Tekstur cookies dipengaruhi oleh lemak yang terkandung didalamnya. Selain itu, perbedaan formula pada tepung mocaf, tepung tempe telur dan tepung ikan lele yang memberikan perbedaan pada sifat fisik kekerasan, tidak mempengaruhi kesukaan panelis terhadap tekstur cookies.

Secara keseluruhan (overall), cookies yang paling disukai oleh panelis adalah cookies F1 dan F2 dengan tingkat nilai kesukaan yang sama yaitu 3,92 . Tingkat kesukaan keseluruhan cookies F3 berbeda nyata dengan cookies F1 dan F2. Cookies F3 masih dalam range nilai kesukaan 3 yang berarti netral. Dari hasil tersebut, secara keseluruhan cookies formula 3 paling tidak disukai diantara kedua formula cookies yang lain.

\section{Karakteristik Kimia}

Analisis karakteristik kimia dilakukan pada ketiga formula cookies bertujuan untuk mengetahui kandungan gizi yang terdapat pada cookies. Hasil analisis karakteristik kimia disajikan Tabel 5. Berdasarkan Tabel 5, kadar air cookies F3 lebih tinggi dibanding F2 dan F1 secara berurutan. Cookies F1 tidak menunjukkan adanya perbedaan nyata dengan cookies F2. Cookies F3 memiliki kadar air paling tinggi yaitu sebesar 6,81 (\%bb) dan berbeda nyata dengan kedua formula cookies yang lain. Hasil tersebut menunjukkan bahwa penambahan mocaf dan tepung ikan lele pada formula cookies akan berpengaruh pada kadar air cookies. Semakin banyak penambahan tepung ikan lele dan semakin sedikit tepung mocaf pada formula cookies, akan menyebabkan kenaikan kadar air pada cookies. Tepung ikan lele memiliki kadar air sebesar $10,93 \%$, sedangkan mocaf yang digunakan pada penelitian memiliki kadar air lebih rendah yaitu 4,29\% (Nurhikmat, 2013). 
Tabel 5. Karakteristik kimia cookies dari campuran tepung mocaf, tempe telur, kacang hijau, dan lele

\begin{tabular}{|c|c|c|c|c|c|}
\hline Parameter & Satuan & SNI & Cookies F1 & Cookies F2 & Cookies F3 \\
\hline Kadar air & $\% \mathrm{bb}$ & Maks. $5^{*}$ & $5,59 \pm 0,07^{a}$ & $6,01 \pm 0,60^{a}$ & $6,81 \pm 0,11^{b}$ \\
\hline \multirow[t]{2}{*}{ Kadar abu } & $\%$ bb & Maks. $1,6^{*}$ & $1,83 \pm 0,07^{a}$ & $1,77 \pm 0,04^{a}$ & $1,85 \pm 0,03^{a}$ \\
\hline & $\%$ bk & - & $1,94 \pm 0,07^{a}$ & $1,88 \pm 0,05^{a}$ & $1,99 \pm 0,04^{a}$ \\
\hline Kadar & $\%$ bb & Min. $5^{*}$ & $10,79 \pm 0,11^{a}$ & $12,06 \pm 0,25^{b}$ & $13,52 \pm 0,11^{\mathrm{c}}$ \\
\hline Protein & $\%$ bk & - & $11,43 \pm 0,11^{a}$ & $12,83 \pm 0,34^{b}$ & $14,47 \pm 0,12^{\mathrm{c}}$ \\
\hline Kadar & $\%$ bb & Min. $9,5^{*}$ & $20,49 \pm 0,65^{a}$ & $20,99 \pm 0,29^{a}$ & $21,37 \pm 0,50^{a}$ \\
\hline Lemak & $\%$ bk & - & $21,69 \pm 0,67^{a}$ & $22,33 \pm 0,30^{a}$ & $23,27 \pm 0,51^{b}$ \\
\hline Kadar & $\% \mathrm{bb}$ & - & $61,31 \pm 0,69^{a}$ & $59,17 \pm 0,77^{b}$ & $56,45 \pm 0,47^{c}$ \\
\hline karbohidrat & $\%$ bk & - & $64,94 \pm 0,78^{a}$ & $62,95 \pm 0,44^{b}$ & $60,58 \pm 0,5^{c}$ \\
\hline Kalori & $\mathrm{Kkal} / 100 \mathrm{~g}$ & Min. $400^{*}$ & $535,08 \pm 17,91^{a}$ & $511,56 \pm 5,64^{a}$ & $522,81 \pm 17,14^{a}$ \\
\hline
\end{tabular}

Keterangan:

Notasi yang berbeda pada baris yang sama menunjukkan beda nyata pada a $5 \%$

Berdasarkan Standar Nasional Indonesia (SNI) 2973:2011, syarat mutu cookies berbahan baku tepung terigu harus memiliki kadar air maksimal 5\% (BSN, 2011).

Pada Tabel 5 terlihat bahwa cookies F1, F2, F3 memiliki kadar abu lebih besar dari SNI cookies yaitu minimal sebesar 1,6 (\%bb). Penggunaan tepung tempe telur, tepung kacang hijau dan tepung ikan lele akan meningkatkan kadar abu cookies. Ketiga bahan tersebut memiliki kadar abu yang jauh lebih tinggi dari tepung terigu. Tepung tempe memiliki kadar abu sebesar 2,33\% (Bastian, 2013), tepung telur memiliki kadar abu sebesar 3,97\% (Angwar, 2007). Tepung kacang hijau mengandung kadar abu sebesar 2,3\% (Sidabutar et al., 2013). Tepung ikan lele memiliki kadar abu yang paling tinggi diantara tepung yang lain yaitu sebesar 4,4\% (Mervina, 2009).

Kadar abu pada ketiga formula cookies tidak berbeda nyata dengan tingkat signifikansi $5 \%$. Kadar abu pada suatu bahan pangan berkaitan dengan kandungan mineralnya. Cookies F3 mempunyai kandungan abu paling tinggi disebabkan rasio penggunaan tepung lele lebih tinggi dibanding formula lain. Ikan lele mengandung mineral relatif tinggi dibanding mocaf, tempe telur dan kacang hijau serta mengandung kalium dan kalsium yang terikat pada protein ikan (Adawyah, 2011). Ketiga formula cookies memiliki kadar protein yang lebih tinggi dibandingkan batas minimal kandungan protein cookies berbahan baku terigu yang ditetapkan oleh SNI
2973:2011 yaitu 5\%. Tepung tempe telur, tepung kacang hijau, dan tepung ikan lele merupakan sumber protein yang dapat meningkatkan kadar protein cookies. Menurut Angwar et al. (2007), kandungan protein pada tepung tempe telur sebesar $42,24 \%$. Tepung kacang hijau sebagai sumber protein nabati memiliki kadar protein sebesar $13,55 \%$ (Sidabutar dkk., 2013). Ikan lele merupakan sumber protein hewani yang memiliki kandungan protein cukup tinggi, yaitu sebesar 63,83\% (Mervina, 2009).

Berdasarkan Tabel 5 diketahui bahwa kadar protein cookies F1, F2, dan F3 berbeda nyata pada tingkat signifikansi $5 \%$. Semakin banyak kandungan tepung ikan lele dan semakin sedikit penambahan tepung mocaf pada formula cookies, maka semakin tinggi pula kadar protein pada cookies. Hal ini dikarenakan kandungan protein pada tepung ikan lele lebih besar dari pada protein pada mocaf (Mervina, 2007; Nurhikmat, 2013).

Angka Kecukupan Gizi (AKG) protein untuk balita per hari adalah 26-35 gram sementara bagi wanita usia subur adalah 56-57 gram (Kemenkes RI, 2013). Berat cookies per keping adalah 25 gram. Artinya dibutuhkan sekitar 8-12 keping cookies bagi balita atau 16-19 keping bagi wanita dewasa untuk mencukupi kebutuhan protein dalam sehari. Namun, keberagaman sumber pangan balita dan dewasa dengan kandungan proteinnya menyebabkan hanya dibutuhkan sekitar 5-10 keping cookies saja untuk mencukupi kebutuhan protein per hari. 
Kadar lemak pada ketiga formula cookies lebih besar dari minimum cookies terigu yang disyaratkan oleh SNI 01-2973-2011 yaitu 9,5 (\%bb). Sumber lemak yang digunakan pada ketiga formula cookies adalah mentega dan kuning telur. Mentega mengandung lemak sebesar $81,6 \%$, sedangkan kuning telur mengandung lemak sebesar 30,31\% (Kemenkes, 2017). Berdasarkan Tabel 5 diketahui bahwa semakin banyak penambahan tepung ikan lele serta semakin rendah penambahan mocaf pada formula cookies, maka semakin tinggi pula kadar lemak pada cookies yang dihasilkan. Hal ini dikarenakan kadar lemak pada tepung ikan lele lebih besar jika dibanding kadar lemak pada tepung mocaf.

Kadar karbohidrat pada ketiga formula cookies berbeda nyata pada tingkat signifikansi $5 \%$. Kadar karbohidrat paling tinggi pada cookies F1 yaitu sebesar 64,94 (\%bk). Kadar karbohidrat paling rendah ada pada cookies F3 dengan kadar karbohidrat sebesar 60,58 (\%bk), sedangkan cookies F2 memiliki kadar karbohidrat sebesar 62,95 (\%bk). Dari hasil tersebut, dapat disimpulkan bahwa semakin tinggi penambahan mocaf semakin tinggi pula kadar karbohidrat pada cookies. Sumber karbohidrat utama pada cookies penelitian ini adalah mocaf. Tepung mocaf merupakan sumber karbohidrat karena memiliki kandungan pati yang cukup tinggi. Jika dibandingkan dengan tepung terigu, kandungan pati pada mocaf lebih besar. Mocaf mengandung pati sebesar $87,3 \%$, sedangkan terigu hanya mengandung pati sebesar $60-63 \%$ (Sunarsi et al., 2011).

Total kalori yang dihasilkan oleh tubuh berasal dari zat gizi makro yang dikonsumsi. Satu gram protein dan karbohidrat dapat menghasilkan lemak sebesar $4 \mathrm{kkal}$. Sedangkan setiap 1 gram lemak menghasilkan energi yang lebih besar yaitu 9 kkal (Winarno, 2008). Dari Tabel 5 dapat dilihat bahwa secara berurutan setiap 100 gram cookies F1, F2, dan F3 memiliki kalori sebesar $535,08 \mathrm{kkal}, 511,56 \mathrm{kkal}$ dan 522,81 kkal. Berdasarkan hasil perhitungan energy menunjukkan tidak adanya perbedaan nyata pada ketiga formula cookies. Ketiga formula cookies tersebut telah sesuai dengan syarat mutu total kalori minimal cookies terigu menurut SNI 012973-2011, yaitu minimal 400 kkal per 100 gram. Menurut Permenkes RI no 75 tahun 2013, AKG energi bagi balita sebesar 1125-1600 kkal sementara bagi wanita usia subur sebesar 2250-2150 kkal. Sehingga konsumsi 200-300 gram cookies (8-12 keping) dapat memenuhi kebutuhan seluruhan energi yang dibutuhkan bagi balita selama sehari. Sementara bagi wanita usia subur, dibutuhkan sekitar 400 gram cookies (16 keping) untuk memenuhi seluruh kalori yang dibutuhkan selama sehari. Dalam sehari, balita ataupun wanita usia subur sudah mengkonsumsi makanan lain terutama makanan utama untuk mencukupi kebutuhan energi. Cookies biasanya dikonsumsi sebagai snack disela-sela waktu makan. Sehingga konsumsi cookies 5-10 keping sudah cukup untuk pemenuhan energi selama 1 hari.

\section{KESIMPULAN}

Cookies hasil formulasi menggunakan tepung mocaf, tepung tempe telur, tepung kacang hijau dan tepung ikan lele dapat digunakan sebagai alternatif makanan cemilan untuk menurunkan resiko stunting dengan jumlah 5-10 keping cookies per hari baik untuk balita dan wanita usia subur. Formula terpilih adalah cookies F2 mempunyai komposisi gizi yaitu protein $12,06 \%$, lemak 20,99\%, karbohidrat $59,17 \%$ dan energy 511,56 $\mathrm{kkal} / 100 \mathrm{~g}$.

\section{SARAN}

Penelitian selanjutnya dapat dilakukan dengan memperkaya komposisi cookies menggunakan bahan pangan tinggi protein serta vitamin dan mineral seperti aneka kacang-kacangan dan produk hasil laut. 


\section{UCAPAN TERIMAKASIH}

Terimakasih pada pimpinan BPTBA-LIPI. Penelitian ini dibiayai dari kegiatan Unggulan LIPI tahun 2016.

\section{DAFTAR PUSTAKA}

Adawyah, R. 2011. Pengolahan dan Pengawetan Ikan. Bumi Aksara: Jakarta

Angwar, M. Ariani, D dan Khasanah, Y. 2007. Optimasi Pembuatan Tepung Tempe Telur Sebagai Salah Satu Bahan Penyusun Tepung BMC Tempe. Jurnal Pangan. ISBN 978-979-16456-0-7.

Bastian, F. Ishak, E. Tawali, B dan Bilang, M. 2013. Daya Terima dan Kandungan Zat Gizi Formula Tepung Tempe dengan Penambahan Semi Refined Carrageenan (SRC) dan Bubuk Kakao. Jurnal Aplikasi Teknologi Pangan. Vol. 2, No. 1.

Badan Penelitian dan Pengembangan Kemenkes RI. 2013. Riset Kesehatan Dasar. Kementerian Kesehatan RI: Jakarta.

BSN. 2011. Mutu dan Cara Uji Biskuit. Badan Standardisasi Nasional: Jakarta.

Halim, NRH. Yusof, HM. Sarbon, NM. 2016. Functional and bioactive properties of fish protein hydolysates and peptides: A comprehensive review. Trends in Food Science \& Technology 51: 24-33.

Hernandez, OH. Mateus, J. Tovar, J. 2012. Starch determination, amylose content and susceptibility to in vitro amylolysis in flours from the roots of 25 cassava varieties. Journal of the Science of Food and Agriculture.

Imandira, P. A. N. 2012. Pengaruh Substitusi Tepung Daging Ikan Lele Dumbo (Clarias gariepinus) dan Tepung Ubi Jalar Kuning (Ipomoea batatas L.) terhadap Kandungan Zat Gizi dan Penerimaan Biskuit Balita Tinggi Protein dan Karoten. Artikel Penelitian. Program Studi IImu Gizi Fakultas Kedokteran Universitas Diponegoro: Semarang.

Kementerian Kesehatan Republik Indonesia. 2017. Data Komposisi Pangan Indonesia. Kementerian Kesehatan Republik Indonesia. Jakarta.

Kocadagli.T., $\quad$ Gokmen.V. 2016. Multiresponse kinetic modelling of Maillard reaction and caramelisation in heated glucose/wheat flour system.
Food Chemistry. Vol.211. 15 November 2016. Pp.892-902.

Ladamay. Arfa, N dan Yuwono, SS. 2014. Pemanfaatan Bahan Lokal Dalam Pembuatan Foodbars (Kajian Rasio Tapioka : Tepung Kacang Hijau Dan Proporsi Cmc). Jurnal Pangan Dan Agroindustri. Vol. 2 No.1, Hal.67-78.

Manley, D. 2001. Biscuit, Cracker, and Cookie Recipes for the Food Industry. Woodhead Publishing Limited: England.

Mervina. 2009. Formulasi Biskuit dengan Substitusi Tepung Ikan Lele Dumbo (Clarias Gariepinus) dan Isolat Protein Kedelai (Glycine Max) sebagai Makanan Potensial untuk Anak Balita Gizi Kurang. Skripsi. Departemen Gizi Masyarakat Fakultas Ekologi Manusia Institut Pertanian: Bogor.

Nurhimat, A. dan Kurniadi, M. 2013. Pengaruh Perendaman Chips Singkong menggunakan Starter Bakteri Asam Laktat pada Pembuatan Tepung Mocaf. Prosiding Seminar Nasional PATPI Jember.

Sánchez, T. Ceballos, H. Dufour, D. Ortiz, D. Morante, N. Calle, F. Felde, TZ. Domínguez, M. Davrieux, F. 2014. Prediction of carotenoids, cyanide and dry matter contents in fresh cassava root using NIRS and Hunter color techniques. Food Chemistry. 151: 444451

Setyaningsih, D. Apriyantono, A. Puspitasari, M. 2010. Sensory Analysis for Food Industry and Agro. IPB Press: Bogor.

Sidabutar,W. Rista, D. Nainggolan, RJ dan Ridwansyah. 2013. Kajian Penambahan Tepung Talas dan Tepung Kacang Hijauterhadap Mutu Cookies. Jurnal Rekayasa Pangan dan Pertanian.Vol.I, No.4.

Sudarmadji, S. Haryono, B. dan Suhardi. 2010. Analisa Bahan Makanan dan Pertanian. Liberty. Yogyakarta

Sunarsi, S. Sugeng AM. Wahyuni, S dan Ratnaningsih, W. 2011. Memanfaatkan Singkong Menjadi Tepung Mocaf untukPemberdayaan Masyarakat Sumberejo. Seminar Hasil Penelitian dan Pengabdian kepada Masyarakat. ISBN 978-602-99172-5-3. Universitas Veteran Bangun Nusantara: Sukoharjo.

Tim Nasional Percepatan Penanggulangan Kemiskinan, 2017, 100 Kabupaten/Kota Prioritas untuk Intervensi Anak Kerdil (Stunting)): 
Ringkasan. Sekretariat Wakil Presiden

Republik Indonesia: Jakarta.

USDA. 2018. USDA Food Composition

Databases.

https://ndb.nal.usda.gov/ndb/. diakses tanggal 24 Juli 2018.

Winarno, F. G. 2008. Kimia Pangan dan Gizi. M-Brio Press. Bogor. 